\title{
THE DEEPEST FINDING OF AN OLM (PROTEUS ANGUINUS): ZAGORSKA PEĆ, OGULIN, CROATIA
}

\author{
NAJGLOBLJA NAJDBA MOČERILA (PROTEUS ANGUINUS): \\ ZAGORSKA PEĆ, OGULIN, HRVAŠKA
}

\author{
Petra KOVAČ KONRAD ${ }^{1} \&$ Katarina KOLLER ŠARIĆ ${ }^{1, *}$
}

\begin{abstract}
UDC 597.92:551.435.85(497.5)

Petra Kovač Konrad \& Katarina Koller Šarić: The deepest finding of an olm (Proteus anguinus): Zagorska peć, Ogulin, Croatia

During the field work in Zagorska peć cave in Croatia, the olm, Proteus anguinus Laurenti, 1768 was observed in a siphon at depth of $113 \mathrm{~m}$. This was not only the first time that this troglobiotic amphibian was recorded at such depths but also the first time that its research was done by cave-divers in its natural environment, at depths greater than $50 \mathrm{~m}$. As such research is dangerous and difficult there was no previous data on the vertical distribution of the olm in the cave system. Further in situ research will provide valuable insight into species' environmental preferences and behaviour.
\end{abstract}

Key words: deep dive, cave system, subterranean environment, the olm, vertical distribution.
Izvleček UDK 597.92:551.435.85(497.5)

Petra Kovač Konrad \& Katarina Koller Šarić: Najgloblja najdba močerila (Proteus anguinus): Zagorska peć, Ogulin, Hrvaška

Močerila, Proteus anguinus Laurenti, 1768, smo med terenskim delom našli v sifonu jame Zagorska peć (Hrvaška), na globini $113 \mathrm{~m}$. Poleg izjemne globine najdbe želimo poudariti, da gre za prvi primer opazovanja te jamske dvoživke v naravnem okolju, ki so ga jamski potapljači izvedli globlje od $50 \mathrm{~m}$. Ker so tovrstni potopi nevarni in težavni, podatkov o vertikalni razporeditvi močerila $\mathrm{v}$ jamskih sistemih doslej še ni bilo. Nadaljnje raziskave in situ lahko prispevajo k boljšemu poznavanju močerilovih prednostnih okolij in vedenja.

Ključne besede: globoki potop, jamski sistem, podzemlje, močeril, vertikalna razporeditev.

\section{INTRODUCTION}

Croatia has a surface area of $56.594 \mathrm{~km}^{2}$, of which the karst terrain covers $26.000 \mathrm{~km}^{2}$, or $46 \%$ (Gottstein Matočec et al. 2002). There are more than 7.000 registered caves in Croatia (Garašić 1991). Their phreatic parts have been poorly studied, mostly due to the high cost and unavailability of diving equipment. Unsystematic cave-diving surveys started in 1959 (Malinar 2015; Kovač Konrad \& Buzjak 2011). Since specific and dangerous survey methods are necessary for surveillance of aquatic subterranean fauna (i.e. stygofauna) in situ, its research has not been systematically conducted.

Alongside many invertebrate groups adapted to subterranean habitats, fish and salamanders are the only obligate subterranean (i.e. troglobiotic) vertebrates (Barr
\& Holsinger 1985). While approximately 300 troglobiotic fish species have been reported so far (Romero et al. 2009), only 13 salamander species of the genus Eurycea Rafinesque, 1822, are widely distributed in eastern and south-central North America, and the olm, Proteus anguinus Laurenti, 1768, inhabits the European Dinaric karst (Chippindale 2000; Wiens et al. 2003).The olm inhabits groundwaters of the Dinaric karst, from Italy, through Slovenia, Croatia, and Bosnia and Herzegovina. (Kletečki et al. 1996; Sket 1997). Prior to the discovery of the first cave fish in the Danube-Aach system (Behrmann-Godel et al. 2017), it was the only European troglobiotic vertebrate (Parzefall et al. 1993). Most of the data about the biology, ecology and behaviour of the olm

\footnotetext{
${ }^{1}$ Association Hyla, Lipovac I No. 7, 10000 Zagreb, Croatia, e-mail: petrakovkon1@gmail.com, katarina.koller@gmail.com Received/Prejeto: 11.06.2017
} 
originate from observations done in an artificial environment (Dumas \& Chris 1998; Vuitron et al. 2011). Consequently, even basic information about the vertical distribution of the olm in subterranean caves is still lacking. While there is some research of vertical distribution of cave invertebrates that live at great depths (Sendra \& Reboleira 2012), there are no data about the vertical distri- bution of vertebrates in the phreatic environment (Sendra \& Reboleira 2012). In Slovenia, the olm was found in Divje jezero (Idrija) at a depth of approximately $50 \mathrm{~m}$ (Krivic et al. 1983). Here we present the first study investigating the vertical distribution of the olm in Zagorska peć Cave in Croatia and the deepest ever record of this cave-dwelling vertebrate.

\section{GEOLOGICAL AND GEOGRAPHICAL SETTING}

Zagorska peć Cave (N: $45.19700^{\circ}$; E: $15.21983^{\circ}$, $350 \mathrm{~m}$ a.s.l.) is situated in the western central part of the Dinaric karst of Croatia, in a part of the Ogulin Zagorje region, Karlovac County, $8 \mathrm{~km}$ south from the town of Ogulin (Fig. 1). The whole area is an example of typical karst hydrogeology characterized by permanent springs at the western margin of the area (Kovač Konrad 2011). Within area we can distinguish true hydrogeological barriers, relative barriers, zones of shallow water in fractures, and zones consisting of deep permeable rocks (Bahun 1970). Zagorska peć is one of six caves within the region (Jalžić 2008) where the olm was found. Other localities include: cave Klisura, Rupečica Spring, Rupečica Ponor, cavespring Zagorska Mrežnica, and Bistrac Spring (Jalžić 2008). Being the deepest cave makes Zagorska peć the most appropriate site to observe the vertical distribution of the olm.

The first cave-diving explorations of Zagorska peć Cave were conducted in 1999 when B. Jalžić and D.

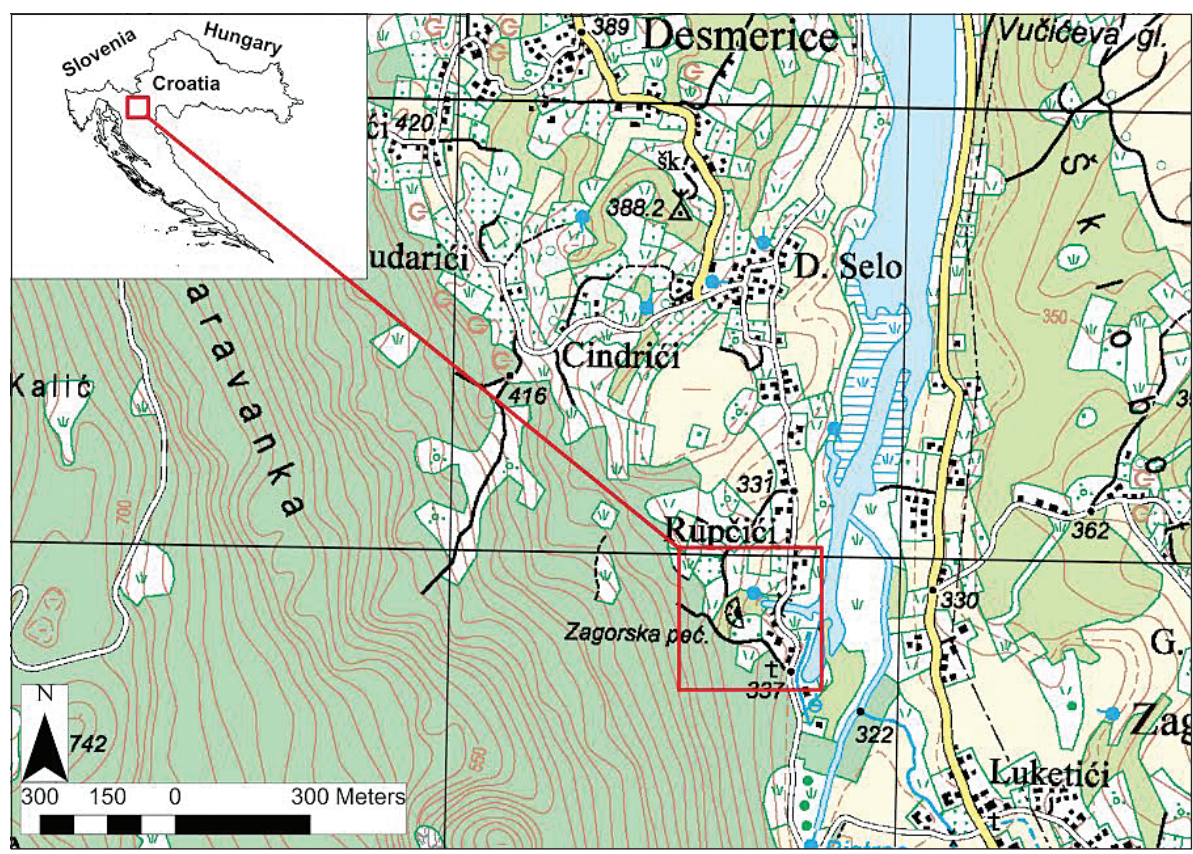

Lukačić dove to $22 \mathrm{~m}$ and confirmed the presence of the olm (Dečak-Barišić et al. 2008). During later cave-diving explorations Zagorska peć Cave and Bistrac Spring were recognised as the only known sites where the olm was found deeper than $50 \mathrm{~m}$ (Jalžić 2008).

The cave map (Fig. 2) shows that Zagorska peć Cave passages are branched, reaching a total length of $490 \mathrm{~m}$. Main passage has a North-South direction. The pattern of the cave system is characterised by numerous fissures and their mutual intersections. A siphon starts in a lake at a depth of $10 \mathrm{~m}$ (Fig. 3), and it continues to a depth of $121 \mathrm{~m}$. In the cave, stable hydrological conditions dominate for relatively long periods, excluding periods of intensive snow-melts or extremely long rainy periods when the cave is partially flooded for several days per year (Bojanić \& Ivčić 1981) and it becomes an active spring. 


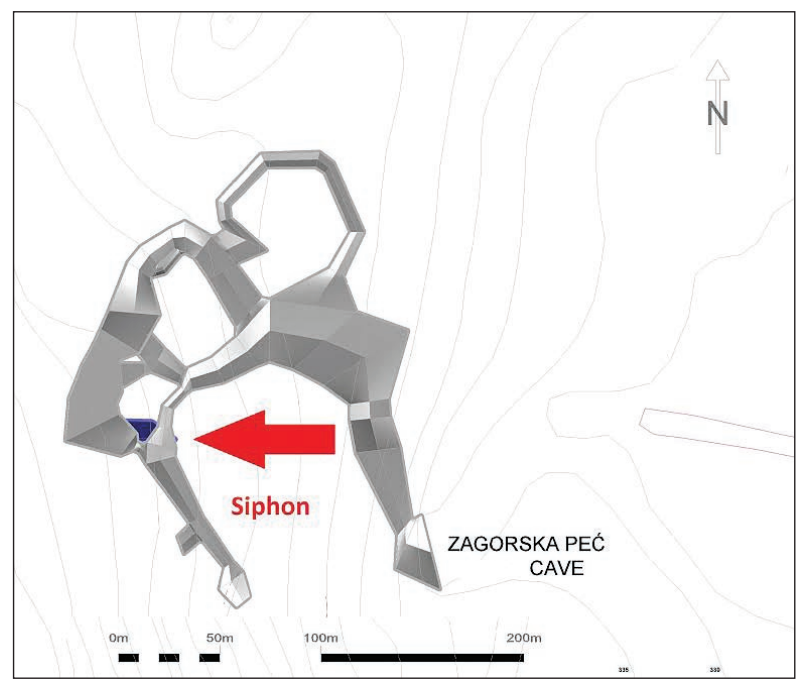

Fig. 2: Cave Map of Zagorska peć Cave, with location of the sampling site -siphon (archive of Caving section Željezničar).

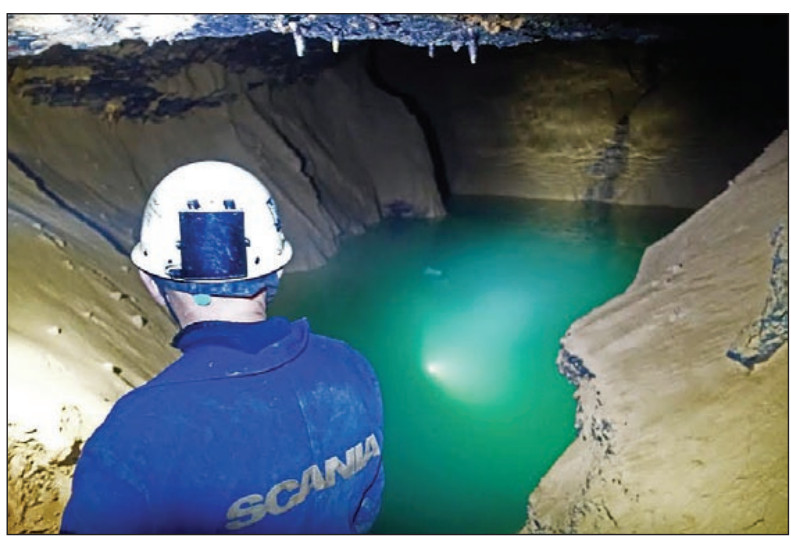

Fig. 3: Lake with syphon (illuminated) in Zagorska peć Cave (Photo: M. Talaja).

\section{METHODS}

Field work in Zagorska peć Cave was conducted on 10. 12. 2016 and 31. 1. 2017 by Frederic Swierczynski, Petra Kovač Konrad and Peter Slokan. The research was carried out with the main purpose of collecting data for studies of vertical distribution of the olms. For the deep cave dives closed-circuit systems for diving (Innerspace Megalodon Model) and a mixture of helium, oxygen and nitrogen gases were used. The water temperature and depth were measured simultaneously with a diving computer (Suunto EON Steel). The depth of each olm was recorded on wet-note. Only olms detected at a 0.5-4 m distance from a safety line $(2 \mathrm{~mm}$ polypropylene line positioned along the siphon which served as the transect line) were recorded. We recommend such consistent and standardised design of data collection for future dives in this and other caves.

\section{RESULTS}

Two successful cave dives deeper than $100 \mathrm{~m}$ (102 m, $121 \mathrm{~m}$ ) were done in Zagorska peć Cave during the data collection. The water temperature during the dives was $8.8^{\circ} \mathrm{C}$. The morphology of the siphon does not change much from its start in the cave lake. It is on average $7 \times 10$ $\mathrm{m}$ wide, with a slight or no water current.

During each dive, 10 adult olms were found along the siphon safety line from $15 \mathrm{~m}$ down to a depth of $113 \mathrm{~m}$ (Tab. 1; Fig. 4). No individuals were noticed in the cave lake, however, neither on this nor on previous occasions. Cave crustaceans (Troglocaris sp., Niphargus sp., Monolistra sp.) were also present all the way down to the deepest parts of the siphon $(121 \mathrm{~m})$.
Tab. 1: Number of the olms, Proteus anguinus, and the depth at which they were recorded.

\begin{tabular}{l|c|c}
\hline Date (total dive depth) & Number of individuals & Depth $(\mathrm{m})$ \\
\hline 10.12. 2016 & 2 & 15 \\
$(102 \mathrm{~m})$ & 1 & 21 \\
& 2 & 30 \\
& 1 & 40 \\
& 1 & 60 \\
& 2 & 70 \\
& 1 & 80 \\
\hline 31.1 .2017 & 2 & 40 \\
$(121 \mathrm{~m})$ & 2 & 60 \\
& 2 & 80 \\
& 2 & 86 \\
& 1 & 98 \\
& 1 & 113 \\
\hline
\end{tabular}




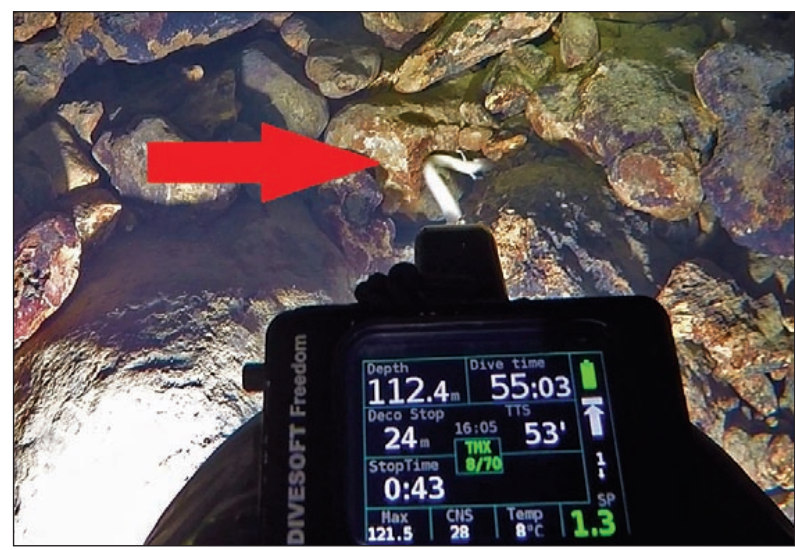

Fig. 4: Proteus anguinus at the depth of $113 \mathrm{~m}$.

\section{DISCUSSION}

This is the first time that the olm, Proteus anguinus, was recorded at such a great depth and also the first time that its observations were done directly by cave divers in its natural environment, at depths greater than $50 \mathrm{~m}$. So far, only two $100 \mathrm{~m}$ plus dives have been performed since such observations require long-term preparation and the dive itself is extremely difficult and dangerous. For deeper dives and possible discovery of the olm at greater depths, the continuation of the siphon should be explored first.

According to our observations, the depth and food sources (as the potential stress factors) have no substantial influence on the proteus' vertical distribution along the siphon of Zagorska peć Cave. Although caves are often held to be extremely energy-poor environments, this apparently doesn't apply to the aforementioned cave. In both dives olms were distributed approximately evenly along the safety line, in accordance with abundant invertebrates, their main source of food (Bizjak-Mali \& Bulog 2004).

In both dives the olms were not recorded at the maximum dive depths. A possible reason could be the divers' complete focus on tying-off the safety line while reaching the maximum dive depth and the planned distance. Nevertheless, since the species was found at such a depth, we could conclude that the olm can withstand significant pressure. Biological structures and processes that allow this creature to dive so deep should also become subjects of future research.

Last but not least, factors like hydrological activity of certain parts of the cave system, its morphology, and sedimentation conditions, should also be considered in further exploration of the olm's vertical distribution.

\section{ACKNOWLEDGEMENTS}

We would like to thank Mladen Zadravec (Association Hyla, Zagreb, Croatia) for his helpful suggestions and comments on the manuscript, Dušan Jelić for doing research on Proteus anguinus in Croatia, Branko Jalžić, Damir Lukačić, Dado Podnar, Vedran Jalžić, Alan Kovačević, Zvonimir Švrljuga, Frederic Swierczynski and Peter Slokan for cave diving research of Zagorska Peć Cave. Our thanks also go to cavers of the Caving section
Željezničar from Zagreb for providing the cave map and logistic support, Caving section Željezničar from Gospić, Mountain rescue team from Gospić for lending their equipment, the director of Gojak Hydroelectric Power Plant Milan Sabljak for hydrological data and a Director of Water supply and Sewerage Ogulin Zdravko Paušić for logistic support. 


\section{REFERENCES}

Bahun, S., 1970: Geološka osnova krške zavale Ogulin Plaški.- Krš Jugoslavije, 7, 1, 19-83.

Barr, T.C. \& J.R. Holsinger, 1985: Speciation in Cave Faunas.- Annual Review of Ecology and Systematics, 16, 313-337.

Behrmann-Godel, J., Nolte, A.W., Kreiselmaier, J., Berka, R. \& J. Freyhof, 2017: The first European cave fish.Current Biology, 27, 7, 257-258. DOI: https://doi. org/10.1016/j.cub.2017.02.048.

Bizjak-Mali, L. \& B. Bulog, 2004: Histology and ultrastructure of the gut epithelium of the neotenic cave salamander, Proteus anguinus (Amphibia, Caudata).- Journal of mophology, 259, 1, 82-89. DOI: https://doi.org/10.1002/jmor.10171

Bojanić, L. \& D. Ivčić, 1981: Hidrogeološka istraživanja područja Drežnica, Krakara, Jasenka, Vitunjčice, Risnjaka i Gojačke Dobre. Fond stručne dokumentacije Geološkog zavoda.

Dumas, P. \& B. Chris, 1998: The olfaction in Proteus anguinus: a behavioural and cytological study.- Behavioural Processes, 43, 2, 107-113. DOI: https://doi. org/10.1016/s0376-6357(98)00002-3.

Chippindale, P.T., 2000: Species boundaries and species diversity in central Texas hemidactyliine plethodontid salamanders, genus Eurycea.- In: Bruce, R., Houck, L. \& R. Jaeger (eds.) The biology of plethodontid salamanders. Kluwer Academic/Plenum, pp. 149-165, New York.

Garašić, M., 1991: Morphological and hidrogeological classification of speleological structures (caves and pits) in the Croatian karst area.- Geološki vjesnik, 44, 289-300.

Gottstein Matočec, S., Bakran-Petricioli, T., Bedek, J., Bukovec, D., Buzjak, S., Franičević, M., Jalžić, B., Kerovec, M., Kletečki, E., Kralj, J., Kružić, P., Kučinić, M., Kuhta, M., Matočec, N., Ozimec, R., Rađa, T., Štamol, V., Ternjej, I. \& N. Tvrtković, 2002: An overview of the cave and interstitial biota of Croatia.- Natura Croatica, 11, 1-112.

Jalžić, V., 2008: Speleoronilačka istraživanja na zapadnoj obali akumulacijskog jezera Sabljaci. Projektni elaborat Hrvatskog biospeleološkog društva u suradnji sa Hrvatskim vodama, 1-7.

Kletečki, E., Jalžić, B. \& T. Rađa, 1996: Distribution of the olm (Proteus anguinus, Laur.) in Croatia.- Memoires de Biospeleologie, 23, 227-231.
Kovač Konrad, P., 2011: Geomorfološka i hidrološka obilježja izvora Zagorske Mrežnice.- Graduation Thesis. Geografski odsjek Prirodoslovno matematičkog fakulteta Sveučilišta u Zagrebu, pp. 43.

Kovač-Konrad, P. \& N. Buzjak, 2011: Primijenjena speleoronilačka istraživanja u zaštiti krških vodonosnika Hrvatske. In: Biondić, D., Holjević, D. \& L. Tropan (eds.) Zbornik radova 5. hrvatske konferencije o vodama s medunarodnim sudjelovanjem: Proceedings of $5^{\text {th }}$ Croatian water conference with international participation, $18^{\text {th }}-21^{\text {th }}$ May 2011, Opatija, Croatia 561-571, Opatija.

Krivic, P., Praprotnik, A. \& R. Smerdu, 1983: Potapljaške raziskave Divjega jezera.- Naše jame, 25, 7-10.

Malinar, H., 2015: Prvo ronjenje u špilji u Hrvatskoj.Velebiten, 48, 61-64.

Parzefall, J., Durand, J.P. \& B. Sket, 1939: Proteus anguinus Laurenti, 1768 - Grottenolm. In: Grossenbacher, K. \& Thismeier B. (eds),Schwanzlurche I, Handbuch der Reptilien und Amphibien Europas. 4/1 Schwanzlurche (Urodela) I. Wiesbaden, AulaVerlag, 7-76.

Romero, A., Zhao, Y. \& X. Chen, 2009: The Hypogean fishes of China.- Environmental Biology of Fishes, 86, 1, 211-278. DOI: https://doi.org/10.1007/ s10641-009-9441-3.

Sendra, A. \& A.S.P.S. Reboleira, 2012: The world's deepest subterranean community - Krubera-Voronja Cave (Western Caucasus).- International Journal of Speleology, 41, 2, 221-230. DOI: https://doi. org/10.5038/1827-806X.41.2.9.

Sket, B., 1997: Distribution of Proteus (Amphibia: Urodela: Proteidae) and its possible explanation.- Journal of Biogeography, 24, 3, 263-280. DOI: https://doi. org/10.1046/j.1365-2699.1997.00103.x.

Voituron, Y., de Fraipont, M., Issartel, J., Guillaume, O. \& J. Clobert, 2011: Extreme lifespan of the human fish (Proteus anguinus): a challenge for ageing mechanisms.- Biological Letters, 7, 1, 105-107. DOI: https://doi.org/10.1098/rsbl.2010.0539.

Wiens, J.J., Chippindale, P.T. \& D.M. Hillis, 2003: When Are Phylogenetic Analyses Misled by Convergence? A Case Study in Texas Cave Salamanders.- Systematic Biology, 52, 4, 501-514. DOI: https://doi. org/10.1080/10635150390218222. 